\title{
Design of Reinforced Concrete Beams Using Two Different Specification
}

\author{
Gumaa A. Hasan*,Mohammed A. Elsageer, Musbah A. Hasan \\ Department of Civil Engineering, College of Engineering, Sirte University, Libya \\ DOI: https://doi.org/10.21467/proceedings.4.19 \\ * Corresponding author email: Gumaa.hasan@yahoo.com
}

\section{ABSTRACT}

Nowadays, reinforced concrete beams are designed using traditional specification, such as BS8110 and Eurocode2 based on truss action. In this research BS8110 and Eurocode2 specification of designing a beam for flexure and shear are studied and compared with each other, to provide an in depth understanding of the two approaches. Two beams are designed, the first beam using BS8110 and the second beam using Eurocode2. The designs based on BS8110 and Eurocode 2 at the ultimate and serviceability limit states are discussed and the approach used to predict deflections is described and checked using standard relationship based on statics. Secondly the BS8110 and Eurocode2 approaches to designing a beam for shear and deflection are compared with each other. the two test beams are tested and the test results are compared with predicted results. The results from the laboratory tests have shown that the Eurocode 2 beam carried a higher load and gave a higher central deflection compared to BS8110.

Keywords: Reinforced Concrete, Beam analysis, shear and deflection.

\section{Introduction}

Concrete is the most important construction material in the construction industry [1, 2]. There are approximately 2,000,000 billion tonnes of concrete being produced yearly [2]. Although concrete is good in compression and a durable material, it is weak in tension, where its tensile strength is approximately $10 \%$ of its compressive strength [3]. Concrete fails in tension when it is exposed to tensile stresses that are greater than its tensile strength capacity. So concrete on its own cannot resist these tensile stresses and it needs to be reinforced with another material that is good in tension, such as steel bars, to prevent failure of concrete in tensile region. Current design approaches for structural concrete beams are based on truss action [4]. In these design approaches the beam is designed firstly for flexure and then forshear independently of each other.

\section{Comparison Between Provisions for Shear in BS8110 And Eurocode2}

\subsection{Shear}

In the design for shear the basic principles behind the approaches in BS8110 and Eurocode2 are the same [5], and they are as follows

(C) 2018 Copyright held by the author(s). Published by AIJR Publisher in Proceedings of First Conference for Engineering

Sciences and Technology (CEST-2018), September 25-27, 2018, vol. 2 .
This is an open access article under Creative Commons Attribution-NonCommercial 4.0 International (CC BY-NC 4.0)

license, which permits any non-commercial use, distribution, adaptation, and reproduction in any medium, as long as the

AijR original work is properly cited. ISBN: 978-81-936820-6-7 
Design of Reinforced Concrete Beams Using Two Different Specification

If the applied shear is less than the shear resistance of the concrete, minimum shear reinforcement should be provided, If the applied shear is higher than the concrete shear strength and less than the maximum design shear, designed shear reinforcement should be provided and if the applied shear is higher than the maximum design shear then a larger section must be chosen.

\subsubsection{Shear Strength of Concrete}

$v c$ in BS8110 is equivalent to $\frac{V R d}{b d}$ in Eurocode2, where $v c$ is design shear stress for concrete, $V R d$ is the shear stress in concrete, $\mathrm{b}$ is the width of the section, and $\mathrm{d}$ is the effective depth of tension reinforcement

In BS8110 and Eurocode2 the strength of the concrete without shear links is dependent on the percentage of tensile reinforcement steel, the concrete grade and the effective depth of section and any axial forces are ignored $[5,6,7]$.

Expression In BS8110

$\mathrm{VC}=\frac{0.79\left[\left(100 \frac{\mathrm{As}}{\mathrm{b} . \mathrm{d}}\right)^{\frac{1}{3}} \times\left(\frac{400}{\mathrm{~d}}\right)^{\frac{1}{4}} \times\left(\frac{\mathrm{fcu}}{25}\right)^{\frac{1}{3}}\right]}{\gamma_{\mathrm{m}}}$

where vc is Shear stress in concrete, As is Area of tensile reinforcement, fcu is Characteristic strength of concrete, and $\gamma_{m}$ is Factor of safety

Expression In Eurocode2

$v_{R d, c}=0.18 \times(1+\sqrt{200 / d}) \times\left(100 \rho_{1} \times f c k\right)^{1 / 3} / \gamma_{m}$

where $\rho_{1}$ is Longitudinal reinforcement ratio, and fck is Characteristic of concrete

The limitations associated with each of these equations are as follows:

Expression In BS8110:

The percentage of tensile reinforcement should not be greater than 3\% [BS8110]

The effective depth $d$ should not be greater than $400 \mathrm{~mm}$ [8]. According to BS8110 the concrete shear capacity increase with depth less than $400 \mathrm{~mm}$.

The ultimate concrete strength $f_{c u}$ should not be greater than $40 \mathrm{~N} / \mathrm{mm}^{2}[\mathrm{BS} 8110,8]$

The factor of safety is 1.25 [BS8110, 8]

Expression In Eurocode2:

The percentage of tensile reinforcement should not be greater than $2 \%[7,8]$

The effective depth $d$ should not be greater than $600 \mathrm{~mm}$

There is no limit placed on the concrete strength $\left(f_{c k}\right)$ [8]

The factor of safety is $1.5[7,8]$

Tables 1 and 2 show the shear stresses for a concrete with a cube strength of $30 \mathrm{~N} / \mathrm{mm}^{2}$ using BS8110 and Eurocode2 
Hasan et al., CEST-2018, AIJR Proceedings 4, pp.518-528, 2018

Table 1: Shear Strength of Concrete BS8110 [8]

\begin{tabular}{|l|l|l|l|l|l|}
\hline & \multicolumn{4}{|l|}{$\mathrm{d}(\mathrm{mm})$} \\
\hline $100 \mathrm{As} / \mathrm{bd}$ & 150 & 250 & 300 & 400 & 600 \\
\hline $0.15 \%$ & 0.46 & 0.4 & 0.38 & 0.36 & 0.36 \\
\hline $0.3 \%$ & 0.57 & 0.51 & 0.48 & 0.45 & 0.45 \\
\hline $1 \%$ & 0.86 & 0.76 & 0.72 & 0.67 & 0.67 \\
\hline $3 \%$ & 1.24 & 1.09 & 1.04 & 0.97 & 0.97 \\
\hline
\end{tabular}

Table 2:Shear Strength of Concrete Eurocode2 [8]

\begin{tabular}{|l|l|l|l|l|l|}
\hline & \multicolumn{4}{|l|}{$\mathrm{d}(\mathrm{mm})$} \\
\hline 100 As $/ \mathrm{bd}$ & 150 & 250 & 300 & 400 & 600 \\
\hline $0.15 \%$ & 0.40 & 0.35 & 0.34 & 0.32 & 0.29 \\
\hline $0.3 \%$ & 0.51 & 0.44 & 0.43 & 0.40 & 0.37 \\
\hline $1 \%$ & 0.75 & 0.66 & 0.63 & 0.60 & 0.55 \\
\hline $3 \%$ & 1.09 & 0.96 & 0.92 & 0.86 & 0.80 \\
\hline
\end{tabular}

\subsubsection{Strength of Concrete Section With Shear Links}

Designing concrete beam in shear using Eurocode2 can lead to significant economies in shear links compared to a beam designed using BS8110 [5, 7]

BS8110 - Assumptions:

- The angle between the notional compressive struts and the axis of the beam is constant and fixed at an angle $45^{\circ}$ [5]

- The lever arm is assumed to be equal to the effective depth of the section [5]

Eurocode2 - Assumptions:

- The angle $\theta^{\circ}$ between the notional compressive struts and the axis of the beam has a value within the range of $22^{\circ}$ to $45^{\circ}[5,7]$.

- $\quad$ The lever arm is assumed to be equal to $0.9 d[5,7]$.

The resulting equations are as follows:

BS8110

$\frac{\mathrm{Asv}}{\mathrm{b} \times \mathrm{Sv}}=\frac{(\mathrm{v}-\mathrm{vc})}{\mathrm{fyv} / \gamma_{\mathrm{m}}}$

where Asv is the area of shear reinforcement, $\mathrm{v}$ is the Shear stress, Sv is the Spacing between links and fyv is Characteristic strength of links

Eurocode2

$\frac{\text { Asw }}{\mathrm{b} \times \mathrm{S}}=\frac{\gamma_{\mathrm{m} \times \mathrm{V}_{\mathrm{Ed}}}}{\text { 0.9.fyk.cot } \theta} \quad$ where $\mathrm{v}_{\mathrm{Ed}}=\frac{\mathrm{V}_{\mathrm{Ed}}}{\mathrm{b} . \mathrm{d}}$

where $\mathrm{v}_{\mathrm{Ed}}$ is the Shear forces at the ultimate limit state, fyk is the Characteristic strength of reinforcement and $\mathrm{S}$ is the Spacing between links

Proceedings of First Conference for Engineering Sciences and Technology (CEST-2018), vol. 2 
Design of Reinforced Concrete Beams Using Two Different Specification

it should be noted that in BS8110 the shear reinforcement does not resist the total applied shear but only resists the shear in excess of that which can be resisted by the concrete $(v-v c)$ [7], where $v$ is the design shear stress and $v c$ is the design concrete shear stress. In Eurocode 2 all the shear must be carried by the shear links, when shear links are required $[5,7]$

\subsubsection{Maximum Shear Strength of Section}

The maximum allowable shear force is limited by placing a limit on the crushing strength of the diagonal compression member to prevent excessive stress from occurring in the diagonal compressive strut and hence prevent compressive strut failure of the concrete.

In BS8110 the maximum allowable shear is dependent on the strut angle and concrete strength, and since the angle of inclination of the strut has a constant value, the maximum shear is dependent only on the concrete strength [7].

$v_{\max }=0.8 \sqrt{f c} \leq 5 \mathrm{~N} / \mathrm{mm}^{2}[B S 8110]$.

where $\mathrm{fc}$ is the Compression stress of concrete

In Eurocode 2 the angle $\theta^{\circ}$ has a value within the range of $22^{\circ}$ to $45^{\circ}$, and hence the maximum shear is a function of the angle $\theta^{\circ}$ and the concrete strength [7].

$v_{R d, \text { max }}=\frac{0.36(1-f c k / 250) \times f c k}{\cot \theta-\tan \theta}[7]$

A comparison of the maximum shear stress permitted within BS8110 and Eurocode 2 is shown in Table 3.

Table 3: Maximum Shear Stress Limitation in BS8110 and Eurocode2 [5].

\begin{tabular}{|l|l|l|l|}
\hline \multirow{2}{*}{ Cube strength $\left(\mathrm{N} / \mathrm{mm}^{2}\right)$} & \multicolumn{2}{|c|}{ Eurocode2 } & \multirow{2}{*}{ BS8110 } \\
\cline { 2 - 3 } & $27^{\circ}$ & $35^{\circ}$ & \\
\hline 25 & 2.91 & 3.38 & 4 \\
\hline 30 & 3.38 & 3.92 & 4.38 \\
\hline 40 & 4.19 & 4.87 & 5 \\
\hline 50 & 4.85 & 5.64 & 5 \\
\hline 60 & 5.36 & 6.22 & 5 \\
\hline
\end{tabular}

\subsubsection{Enhanced Shear Near Supports}

BS8110 and Eurocode2 allow greater shears to be resisted by a concrete section which is close to the supports of a beam. The enhancement is a function of the $a v / d$ ratio where $\mathrm{d}$ is the effective depth of the section and $a v$ is the distance from the section considered to the face of the beam support. In BS8110, the design concrete shear stress $v c$, can be enhanced by $2 d / a v$ where $2 d$ is greater than $a v$. In Eurocode 2 the shear which can be resisted by the concrete without shear links, can be enhanced by $2.5 \mathrm{~d} / \mathrm{av}$ where $2.5 \mathrm{~d}$ is 
greater than $a v[5,6]$. Eurocode2 allows a slightly higher enhancement of the shear capacity than BS8110, so benefits are less in the case of BS8110 compared to Eurocode2 [8]

\subsubsection{Spacing Of Links}

\section{BS8110}

"The spacing of links in the direction of the span should not exceed $0.75 \mathrm{~d}$. At right-angles to the span, the horizontal spacing should be such that no longitudinal tension reinforcing bar is more than $150 \mathrm{~mm}$ from a vertical leg; this spacing should in any case not exceed d"[?] Eurocode2

In Eurocode2 the spacing is a function of the applied shear. The rules are shown in Table 4.

Table 4: Spacing between Links [5, 6]

\begin{tabular}{|c|c|c|}
\hline \multirow{2}{*}{ Applied Shear } & \multicolumn{2}{|c|}{ Spacing $(\mathrm{mm})$} \\
\cline { 2 - 3 } & Lateral Spacing & Longitudinal Spacing \\
\hline$v<v_{\max } \times 1 / 5$ & $d \leq 800$ & $0.8 d \leq 300$ \\
\hline$v_{\max } \times 1 / 5<v<v_{\max } \times 2 / 3$ & $0.6 d \leq 300$ & $0.6 d \leq 300$ \\
\hline$v>v_{\max } \times 2 / 3$ & $0.3 d \leq 200$ & $0.3 d \leq 200$ \\
\hline
\end{tabular}

\subsubsection{Additional Tensile Forces}

In Eurocode 2 the tensile force in the bottom tension member is given by:

$F S=M / Z+1 / 2 \times V_{E d} \times \cos \theta$

where Fs is the Tensile stress of reinforcement, $M$ is the Design ultimate moment, and $Z$ is the Lever arm.

The second term in this equation is related to the shear forces in the links, so Eurocode 2 takes into account the tensile forces which are caused by the bending and shear force in the links.

BS8110 takes into account only the first term in this equation (the bending term) and ignores the tensile force which is caused by shear force (second term in this equation).

\subsection{Deflection}

1- The assumptions which are required to define the behavior of a section under any loading condition are as follows:

BS8110

In an un-cracked section the reinforcement and the concrete in tension and compression are assumed to behave elastically. The modulus of elasticity of the reinforcement may be taken as $200 \mathrm{kN} / \mathrm{mm}^{2}$ and for the concrete may be taken from BS8110-2:1985, Section 3.5

In a cracked section the reinforcement in tension and compression is assumed to behave elastically and the concrete in compression is also assumed to behave elastically but in the tension region the concrete is assumed to behave linearly from zero stress at the neutral axis

Proceedings of First Conference for Engineering Sciences and Technology (CEST-2018), vol. 2 
to a limiting stress of $1 \mathrm{~N} / \mathrm{mm}^{2}$ at the centroid of the tensile reinforcement for short term loading and $0.5 \mathrm{~N} / \mathrm{mm}^{2}$ for long term loading. [9].

\section{Eurocode2}

In an un-cracked section the reinforcement and concrete in tension and compression are assumed to behave elastically [5]. The modulus of elasticity for the reinforcement can assumed to be $200 \mathrm{kN} / \mathrm{mm}^{2}$.

In a cracked section the reinforcement in tension and compression is assumed to behave elastically and the concrete in compression is assumed to behave elastically but in tension the concrete stress is ignored. [7].

Where BS8110 assumes that the tensile strength of concrete is approximately $1 \mathrm{~N} / \mathrm{mm}^{2}$ and Eurocode2 uses a significantly higher value than BS8110 [5].

\section{2- Curvature}

According to Narayanan [18], see Figure 1 (a parameterized moment-curvature diagram), when $M / b d^{2}$ is in between 0.3 and 0.6 , BS8110 gives higher curvature values than Eurocode2. This is because BS8110 uses a value for the tensile strength of concrete of approximately $1 \mathrm{~N} / \mathrm{mm}^{2}$ and Eurocode2 uses a much higher value. In general terms BS8110 and Eurocode2 are more or less equivalent.

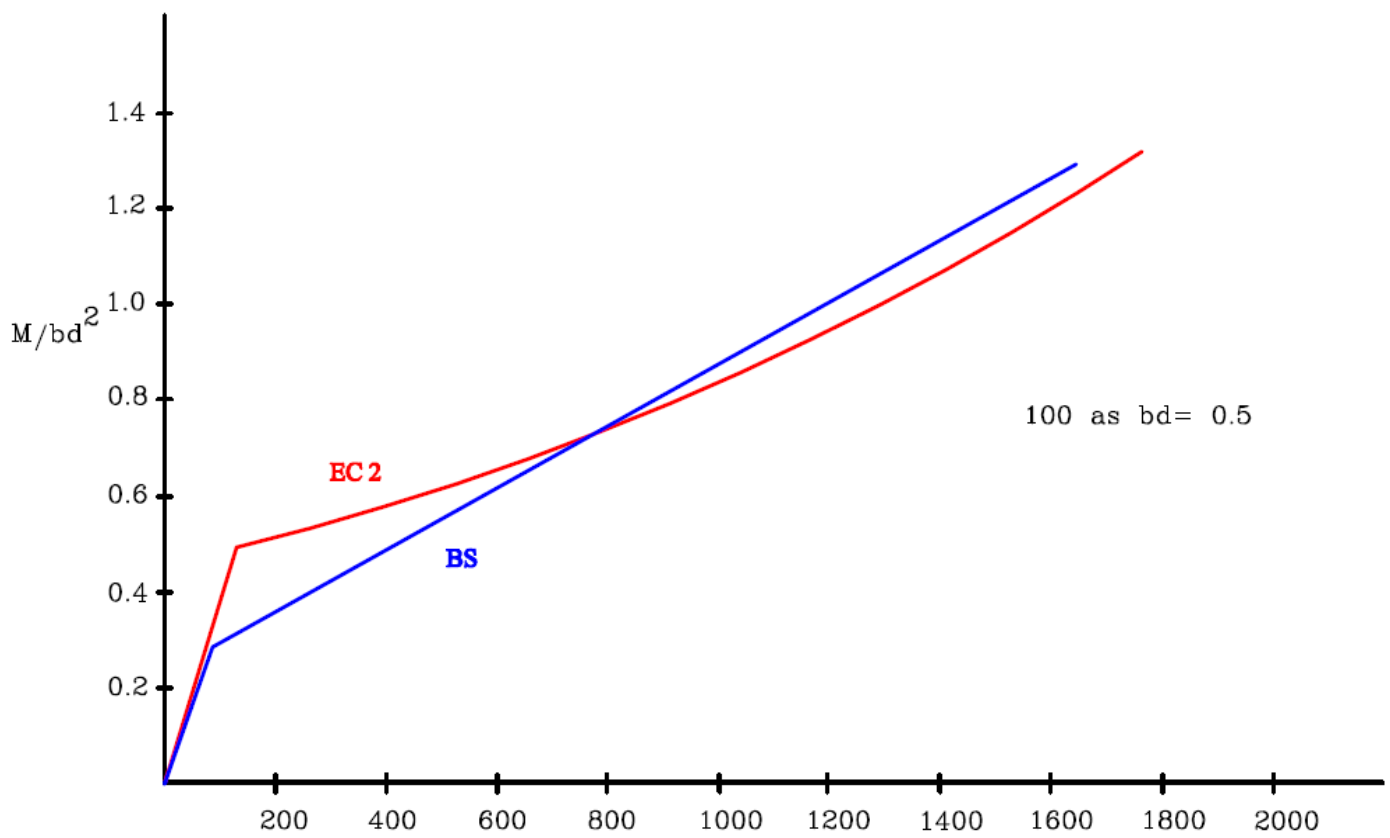

Figure 1: Comparison of Curvatures Predicted by BS8110 and Eurocode2 [18] 


\subsection{Economic Study}

The Table 5 shows that the traditionally designed beams, which have been designed using BS8110 and Eurocode2, the weights of the reinforcement are $38.48 \mathrm{~kg}$ and $39.78 \mathrm{~kg}$ respectively.

Table 5: Weight and Cost of Reinforcing Bars in Beam

\begin{tabular}{|c|c|c|c|c|c|c|c|c|}
\hline & $\begin{array}{c}\text { Size } \\
\text { of } \\
\text { bar }\end{array}$ & $\begin{array}{c}\text { No. } \\
\text { Of } \\
\text { bars }\end{array}$ & $\begin{array}{c}\text { Length } \\
\text { of bar } \\
(\mathrm{m})\end{array}$ & $\begin{array}{c}\text { Total } \\
\text { length of } \\
\text { bars (m) }\end{array}$ & $\begin{array}{c}\text { Density } \\
\text { of bar }\end{array}$ & $\begin{array}{c}\text { Weight } \\
\text { of bar } \\
(\mathrm{kg} / \mathrm{m})\end{array}$ & $\begin{array}{c}\text { Total } \\
\text { weight } \\
\text { of bars } \\
(\mathrm{kg})\end{array}$ & $\begin{array}{c}\text { Weight } \\
\text { of beam } \\
(\mathrm{kg})\end{array}$ \\
\hline \multirow{2}{*}{$\begin{array}{c}\text { Beam (1) } \\
\text { BS8110 }\end{array}$} & 6 & 23 & 1.178 & 27.094 & 7.8 & 0.220 & 5.97 & \multirow{2}{*}{38.48} \\
\cline { 2 - 10 } & 20 & 3 & 3.85 & 11.55 & 7.8 & 2.45 & 28.297 & \\
\hline \multirow{2}{*}{$\begin{array}{c}\text { Beam (2) } \\
\text { Eurocode2 }\end{array}$} & 6 & 28 & 1.178 & 32.984 & 7.8 & 0.220 & 7.27 & \multirow{2}{*}{39.78} \\
\cline { 2 - 9 } & 20 & 3 & 3.85 & 11.55 & 7.8 & 2.45 & 28.297 & \\
\hline
\end{tabular}

\section{Details of Materials and Test Procedure}

\subsection{Description of Beams and Loading Arrangement}

Two beams were prepared for the laboratory based test programme with a rectangular crosssection of $200 \mathrm{~mm} \times 300 \mathrm{~mm}$, an overall length of $3500 \mathrm{~mm}$, an effective span of $3000 \mathrm{~mm}$ and a minimum cover of $25 \mathrm{~mm}$.

The two beams were tested using a four point loading arrangement the loading points were located at distance equal to $662.5 \mathrm{~mm}$ from the centerline of each support, see Figure 2, the spacing was based on Kani's Valley.

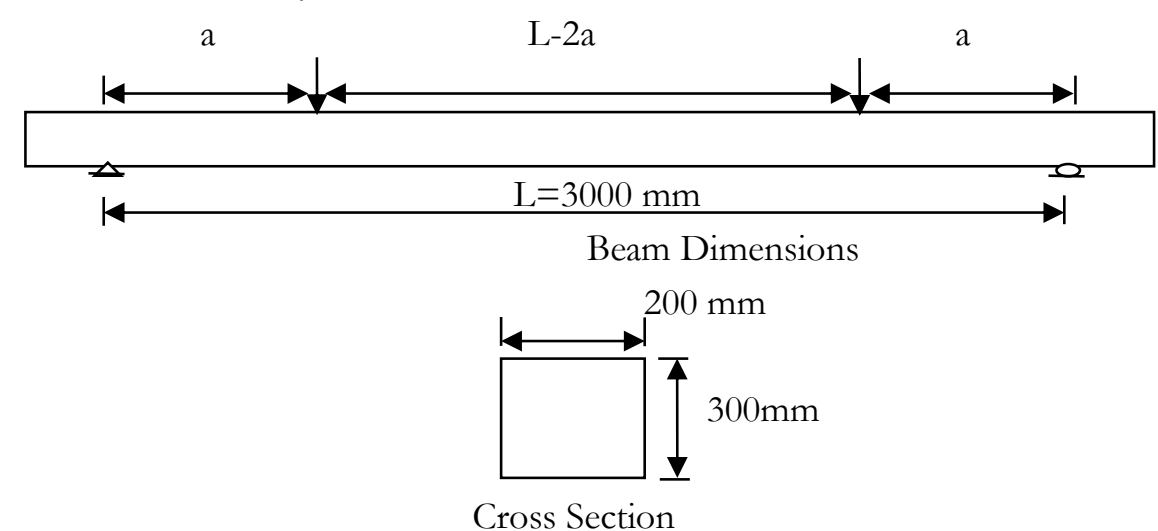

Figure 2: Details of Beam and Loading Arrangement 
Design of Reinforced Concrete Beams Using Two Different Specification

\subsection{Design Of Test Beams}

The beams were designed using two design approaches i.e. BS8110 Part 1 [1] and Eurocode2 [7]. The first beam was designed using the approach described in BS8110 and the secondbeam was designed using the approach in Eurocode2. Table 6 provides details of the three beams.

Table 6: Beam Specifications

\begin{tabular}{|c|c|c|c|}
\hline Beam & $\begin{array}{c}\text { Cross-section } \\
\left(\mathrm{mm}^{2}\right)\end{array}$ & $\begin{array}{c}\text { Tensile bars } \\
\left(\mathrm{mm}^{2}\right)\end{array}$ & Spacing of links $(\mathrm{mm})$ \\
\hline BS8110 & $(200 \times 300)$ & $3 T 20$ & T6 at 150 \\
\hline Eurocode2 & $(200 \times 300)$ & $3 T 20$ & T6 at 100 \\
\hline
\end{tabular}

\subsection{Details of Reinforcement}

Three sizes of reinforcing bars were used and they are as follows:

- $6 \mathrm{~mm}$ diameter reinforcing bars were used as shear reinforcement in all three beams.

- $10 \mathrm{~mm}$ diameter reinforcing bars were used as hanger bars for the links in all three beams.

- $\quad 20 \mathrm{~mm}$ diameter reinforcing bars were used as tensile reinforcement in all three beams. The three barsizes were tested to obtain the mechanical properties using of the steel. Tables 7, 8 and 9 show the tensile test results. All reinforcing bars were high yield steel.

Table 7: Tensile Test Results for $6 \mathrm{~mm}$ Diameter Reinforcing Bars

\begin{tabular}{|c|c|c|c|}
\hline Test & $\begin{array}{c}\text { Maximum load } \\
(\boldsymbol{k} \boldsymbol{N})\end{array}$ & $\begin{array}{c}\text { Tensile strength } \\
\left(\mathbf{N} / \mathbf{m m}^{\mathbf{2}}\right)\end{array}$ & $\begin{array}{c}\text { Young's modulus } \\
\left(\mathbf{N} / \mathbf{m m}^{\mathbf{2}}\right)\end{array}$ \\
\hline Test 1 & 16.61 & 588 & 196 \\
\hline Test 2 & 16.51 & 584.1 & 194 \\
\hline average & 16.015 & 567 & 195 \\
\hline
\end{tabular}

Table 8: Tensile Test Results for $10 \mathrm{~mm}$ Diameter Reinforcing Bars

\begin{tabular}{|c|c|c|c|}
\hline Test & $\begin{array}{c}\text { Maximum load } \\
(\boldsymbol{k} N)\end{array}$ & $\begin{array}{c}\text { Tensile strength } \\
\left(\mathbf{N} / \mathbf{m m}^{\mathbf{2}}\right)\end{array}$ & $\begin{array}{c}\text { Young's modulus } \\
\left(\mathbf{N} / \mathbf{m m}^{\mathbf{2}}\right)\end{array}$ \\
\hline Test 1 & 49 & 624 & 197 \\
\hline Test 2 & 47.98 & 611 & 202 \\
\hline average & 48.49 & 617.5 & 199.5 \\
\hline
\end{tabular}

Table 9: Tensile Test Results for $20 \mathrm{~mm}$ Diameter Reinforcing Bars

\begin{tabular}{|c|c|c|c|}
\hline Test & $\begin{array}{c}\text { Maximum load } \\
(\boldsymbol{k N})\end{array}$ & $\begin{array}{c}\text { Tensile strength } \\
\left(\mathbf{N} / \mathbf{m m}^{\mathbf{2}}\right)\end{array}$ & $\begin{array}{c}\text { Young's modulus } \\
\left(\mathbf{N} \mathbf{m ~ m}^{\mathbf{2}}\right)\end{array}$ \\
\hline Test 1 & 203.2 & 647 & 211 \\
\hline Test 2 & 199.47 & 635.25 & 205 \\
\hline average & 201.33 & 641.13 & 208 \\
\hline
\end{tabular}




\subsection{Details Of The Concrete}

Six cubes and six cylinders were taken from the concrete mix in order to obtain the concrete crushing strengths at the time the beams were tested. These results were used to obtain the best estimate of the flexural/shear capacities of the beams and also the deflection values for the beams i.e. two sets of calculation were prepared one set assuming the concrete strength to be $30 \mathrm{~N} / \mathrm{mm}^{2}$ and the second set using actual concrete strength obtained from the cubes and cylinders. The material and load safety factors were moved from all the calculations used to predict the flexural and shear carrying capacities and the deflections of the beams. Tables 10 and 11 show the results obtained from the cube and cylinder tests carried out at the time the beams were tested.

Table 7:Concrete Cube Crusbing Test Results

\begin{tabular}{|c|c|c|c|c|c|c|}
\hline $\begin{array}{c}\text { Ten day } \\
\text { strength }\end{array}$ & $\begin{array}{c}\text { Weight of cube } \\
(\mathrm{g})\end{array}$ & $\begin{array}{c}\mathrm{H}_{1} \\
(\mathrm{~mm})\end{array}$ & $\begin{array}{c}\mathrm{H}_{2} \\
(\mathrm{~mm})\end{array}$ & $\begin{array}{c}\mathrm{H}_{3} \\
(\mathrm{~mm})\end{array}$ & $\begin{array}{c}\text { Applied loading } \\
(\mathrm{kN})\end{array}$ & $\begin{array}{c}f_{c u} \\
(\mathrm{~N} \\
\left./ \mathrm{mm}^{2}\right)\end{array}$ \\
\hline Cube 1 & 2417 & 100 & 100 & 100 & 182 & 18.2 \\
\hline Cube 2 & 2518 & 100 & 100 & 100 & 200.4 & 20.04 \\
\hline Cube 3 & 2442 & 100 & 100 & 100 & 195.3 & 19.53 \\
\hline Cube 4 & 2421 & 100 & 100 & 100 & 211 & 21.1 \\
\hline Cube 5 & 2420 & 100 & 100 & 100 & 180.7 & 18.07 \\
\hline Cube 6 & 2400 & 100 & 100 & 100 & 203.4 & 20.34 \\
\hline
\end{tabular}

Table 8: Concrete Cylinder Crusbing Test Results

\begin{tabular}{|c|c|c|c|c|c|}
\hline $\begin{array}{c}\text { Ten day } \\
\text { strength }\end{array}$ & $\begin{array}{c}\text { Weight of cube } \\
(\mathrm{kg})\end{array}$ & $\begin{array}{c}\text { Diameter } \\
(\mathrm{mm})\end{array}$ & $\begin{array}{c}\text { high } \\
(\mathrm{mm})\end{array}$ & $\begin{array}{c}\text { Applied loading } \\
(\mathrm{kN})\end{array}$ & $\begin{array}{c}f_{c K} \\
(N \\
\left./ \mathrm{mm}^{2}\right)\end{array}$ \\
\hline Cylinder 1 & & 150 & 300 & 214.5 & 12.4 \\
\hline
\end{tabular}

Average cube strength $=19.54 \mathrm{~N} / \mathrm{mm}^{2}$

Average cylinder strength $=12.4 \mathrm{~N} / \mathrm{mm}^{2}$

\section{Results From Laboratory Based Test Programme}

\subsection{BS8110 Beam}

According to the results from the laboratory based test, the maximum failure load was $80 \mathrm{kN}$ and the maximum deflection at mid span was $11.64 \mathrm{~mm}$. Figure 3 shows the relationship between the applied load and central deflection of the beam. 
Design of Reinforced Concrete Beams Using Two Different Specification

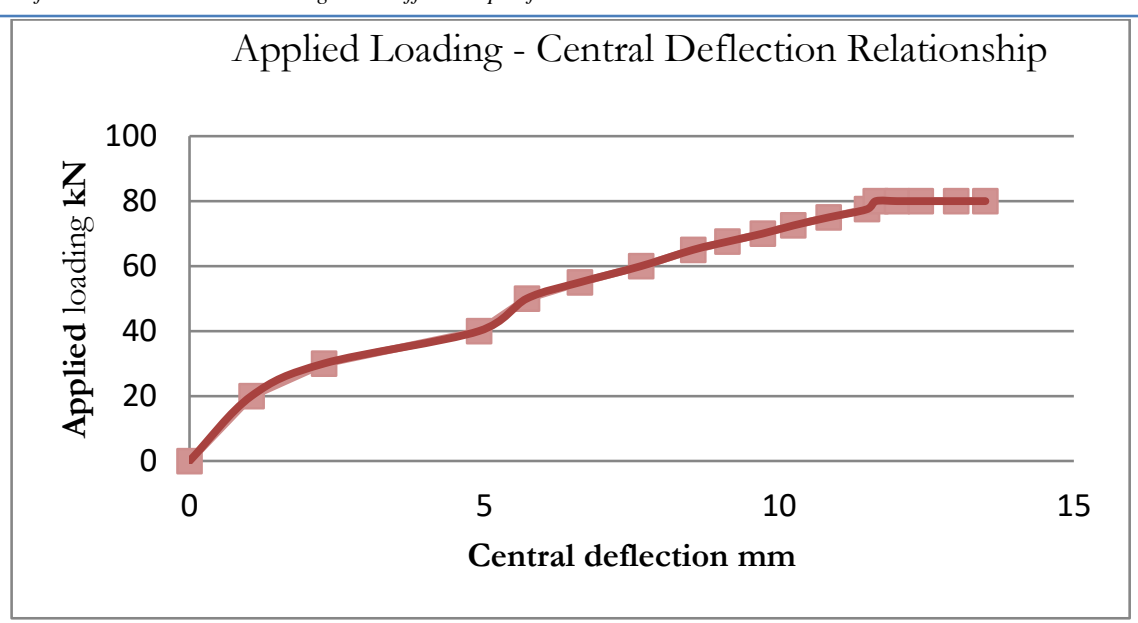

Figure 3: Applied Load-Central Deflection Relationship

\subsection{Eurocode2 Beam}

The maximum applied load at failure for the Eurocode 2 Beam was $95 \mathrm{kN}$ and the maximum deflection at mid span at failure was $24 \mathrm{~mm}$. Figure 4 shows the corresponding applied load deflection relationship.

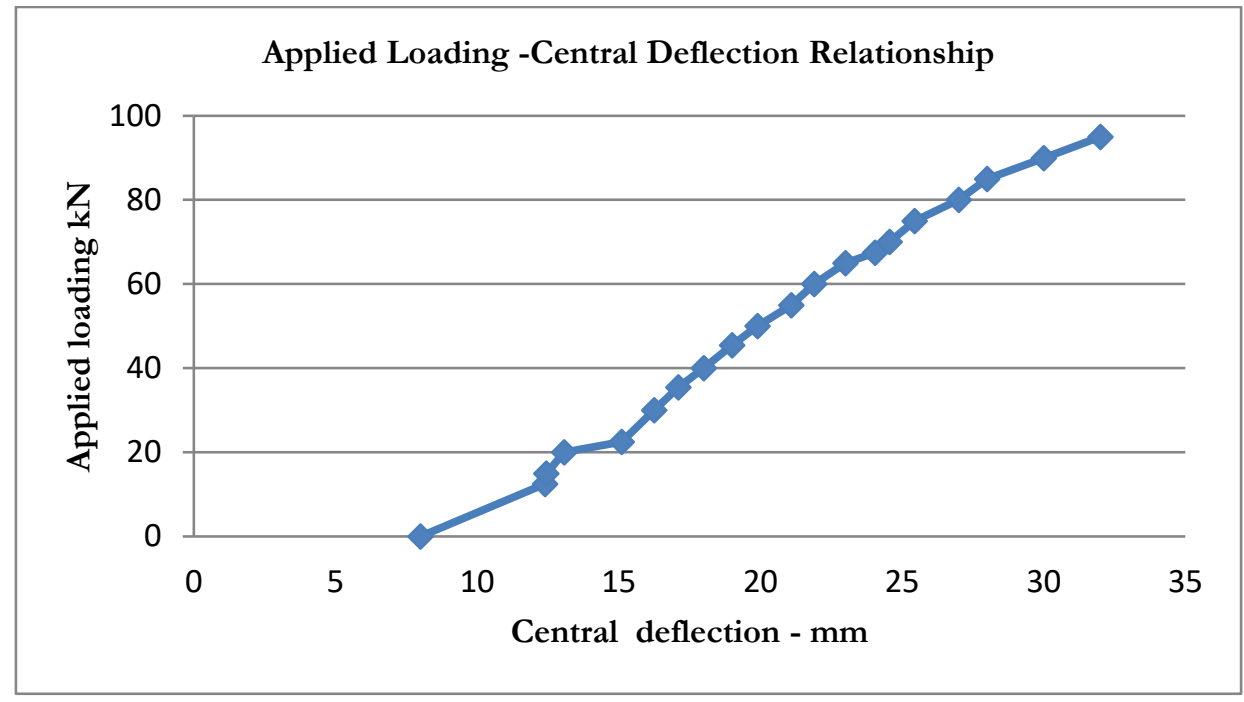

Figure 4: Applied Loading-Central Deflection Relationship

\section{Conclusion}

1. The BS8110 and Eurocode2 beams failed in shear before reaching their ultimate flexural capacity.

2. The Eurocode 2 specification is much easier to follow than the specification detailed in BS8110

3. The Eurocode 2 specification requires less shear reinforcement than the BS8110 specification

4. BS8110 and Eurocode2 are similar in that 
- The shear stress depends on the effective depth and tensile reinforcement ratio and the concrete strength

- There is a shear stress below which only minimum shear reinforcement need be provided

5. BS8110 and Eurocde2 are different in that

- In BS8110 the shear reinforcement does not resist all the applied shear but resists only the shear in excess of that which can be resisted by the concrete $(v-v c)$ [18], where $v$ is the design shear stress and $v c$ is the design concrete shear stress. In Eurocode2 the shear must be carried by the shear links, when the shear links are required

- The BS8110 specification gives a higher value of $v_{c}$ than is obtained from Eurocode2 for C30 concrete

- Eurocode2 permits significantly higher shears to be resisted by a section than does BS8110

- The scope of the approach in Eurocode 2 is more extensive than the specification used in BS8110 for instance in Eurocode2 there is no limit placed on the concrete strength and designer is free to chosen any angle of inclination of the compression strut between $22^{\circ}$ and $45^{\circ}$ [8].

- In Eurocode2 the designer can seek out economies in the provision of shear reinforcement.

6. The results from the laboratory tests have shown that the Eurocode 2 beam carried a higher load $(95 k N)$ and gave a higher central deflection (24mm) compared to BS8110 beam which failed under a load of $80 \mathrm{kN}$ and a maximum central deflection of $13.5 \mathrm{~mm}$.

\section{References}

[1] MacGinley T J, Choo B S, Reinforced concrete, design theory and examples. Second edition, 1990.

[2] Royal Society of Chemistry, The Concrete conundrum. Available on: http://www.rec.org/chemistryworld/restricted/2008/Msrch/TheConcreteConundrum. asp.

[3] Gambhir M L, Concrete Technology, 2004.

[4] Kuttab, A S and Haldane, Detailing for shear with the compressive force path concept. Proceeding of the IABSE Colloquium. Structural Concrete, Vol 69 No: 6, pp74-150, 1991.

[5] Narayanan R S, Concrete structures: Eurocode EC2 \& BS8110 Compared, 1994.

[6] Hulse R, Monypenny P C, An instruction to EC2 and comparison with BS8110, 1993.

[7] Mosley W, Bungey J, and Hulse R, Reinforced concrete design to Eurocode2. Sixth Edition, 2007.

[8] Moss, R. EN1992-Eurocode and BS8110 Compared. Proceedings of the Institution of Civil Engineers - Civil Engineering, Volume: 156 Issue: 3, Aug 2003.

[9] British Standard BS8110, Structural use of concrete of concrete - Part 1: Code of practice for design and construction, 1997. 